\title{
Simple surgical solution: scaphoid type congenital megalourethra
}

\author{
Kashish Khanna, ${ }^{1}$ Deepak Bagga, ${ }^{2}$ Amit Kumar Jadhav, ${ }^{2}$ Rajat Piplani ${ }^{2}$
}

'Department of Pediatric Surgery, All India Institute of Medical Sciences, New Delhi, India

${ }^{2}$ Pediatric Surgery Department, Vardhman Mahavir Medical College and Safdarjung Hospital, New Delhi, India

Correspondence to Dr Kashish Khanna, kash.modern@gmail.com

Accepted 9 January 2018
Check for updates

To cite: Khanna K, Bagga D, Jadhav AK, et al. BMJ Case Rep Published Online First: [please include Day Month Year]. doi:10.1136/bcr-2017222936

\section{DESCRIPTION}

Congenital megalourethra (CM) is an uncommon paediatric urogenital problem with less than 80 reported cases ${ }^{1}$ and may go ignored for years. It is defined as dilatation and elongation of the penile urethra associated with the deficiency of the corpora cavernosa and/or spongiosum. It may be of scaphoid or fusiform variety. However, surgery in most cases may be challenging.

A 10-year-old boy presented with the complaint of a swelling appearing on the under-surface of the penis during voiding since birth. This persisted even after micturation and had to be milked out post voiding. His urinary stream was of good calibre and normal volume. There was no associated history of urinary tract infection or obstruction. External genital examination was normal with bilateral descended testes, stretched penile length $=4.5 \mathrm{~cm}$, normal prepuce and normally positioned urethral meatus. However, dilatation of the dorsal penile shaft was observed during micturation. A retrograde cum voiding cystourethrography revealed dilatation of the anterior urethra (maximum diameter $=1.68 \mathrm{~cm}$ ), normal posterior urethra, urinary bladder and no reflux (figure $1 \mathrm{~A}, \mathrm{~B}$ ). With the provisional diagnosis of CM, the child was taken up for surgery.

Under general anaesthesia, child in supine position, after ruling out distal obstruction, a midline skin incision was given over the protuberant portion of the dorsal penile shaft. It was developed in layers

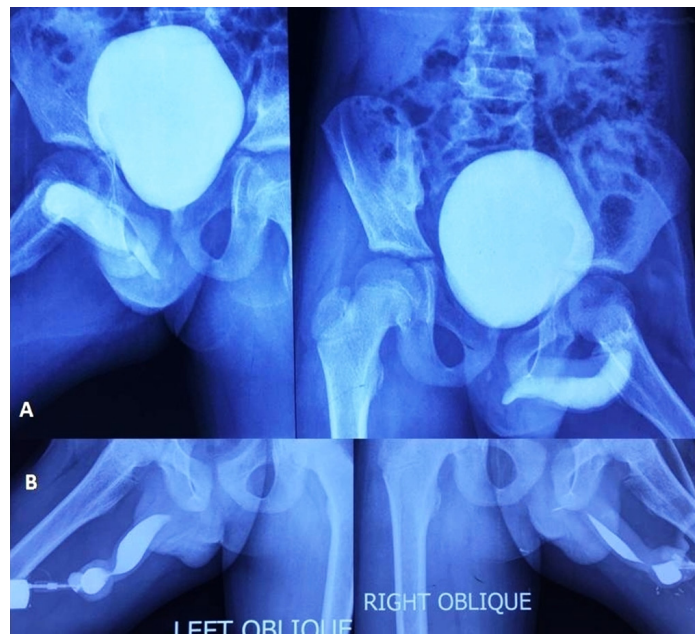

Figure 1 (A) Micturating cystourethrogram showing the dilated anterior urethra, normal posterior urethra and bladder with no vesicoureteric reflux. (B) Retrograde urethrogram showing scaphoid-like dilatation of the anterior urethra.

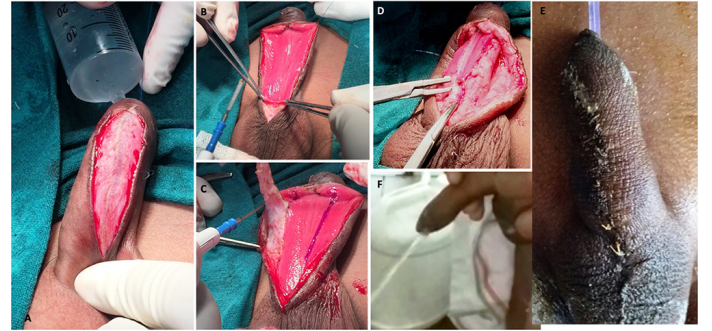

Figure 2 (A) Vertical midline incision till the mucosa of the scaphoid congenital megalourethra. (B) Lay open of anterior dilated megalourethra. (C) Marking and tapering off excessive urethra. (D) Tubularisation over no. 10 infant feeding tube in two layers. (E) Complete repair post dressing removal. (F) Postoperative disappearance of dorsal penile shaft swelling during voiding and a good urinary stream.

up till the mucosal lining of the anterior urethra (figure 2A), laying it open (figure 2B). Marking of excessive urethra was done. This excessive urethral mucosa was trimmed on either side as well as distally till the normal urethra was identified (figure 2C). Urethral tubularisation was done over $10 \mathrm{~F}$ infant feeding tube (IFT) in two layers with polydioxanone 6.0 suture (continuous and then interrupted) (figure 2D). Deficient spongiosum was then sutured in interrupted technique over the previous suture line. Skin over the dorsal penile shaft was de-epithelised. Double breasting of the de-epithelised skin along with underlying dartos tissue was done to attain additional support in place of the deficient spongiosum layer. The skin was approximated in the midline with interrupted polyglactin 5.0 rapid suture. Recovery was uneventful. Dressing was removed on Day 7 (figure 2E) and catheter on Day 10. Postoperatively, the initial complaint of the child of penile shaft swelling during micturation disappeared and so did the post-void dribbling (figure 2F).

CM usually do not have a true distal anatomical obstruction and hence differ from congenital urethral diverticula which have narrow orifices causing distal obstruction. CM is associated with abdominal wall defects like prune belly syndrome and other urogenital tract anomalies in nearly $85 \%$ of the cases. ${ }^{2}$ Scaphoid variety has the absence of hypoplastic spongiosum layer. Nesbitt proposed the surgery for $\mathrm{CM}^{3}$ Our technique ensures a multilayered, single-staged repair by providing an extra layer of double-breasted dartos tissue. This provides additional support, good cosmesis and probably decreased fistula rate in such cases. This technique is easy to learn and follow, and hence can be practised 
by most surgeons in such cases of CM. An IFT has commonly been used as a urethral stent in hypospadias repair. Similarly, in our case, an IFT served as an atraumatic, cheap and easily available per-urethral stent. Unlike a catheter which may not deflate completely and cause subsequent trauma to the repaired suture line during removal, an IFT could be removed smoothly with utmost ease. Few other authors have reported good results with similar technique of reduction urethroplasty in isolated cases of scaphoid CM. ${ }^{12}$ However, the surgical techniques for repair of

\section{Learning points}

Congenital megalourethra can present for the first time even in boys of prepubertal age group.

- A good quality preoperative cystourethrogram is necessary to plan the type of surgery.

- Urethral tapering, tubularisation, spongiosus cover with double breasting of dartos tissue and skin closure offer a simple surgical solution in scaphoid variety of megalourethra.
CM have not yet been standardised because of the small number of cases reported in literature.

Contributors The case was admitted under the care of DB. All authors were involved in the diagnosis and management of this case. The child was operated upon by DB and AKJ, and KK has collected the data, envisaged and drafted the manuscript. The revision of the manuscript was done by DB, KK, RP and AKJ. All authors have approved the manuscript for final submission.

Funding This research received no specific grant from any funding agency in the public, commercial or not-for-profit sectors.

Competing interests None declared.

Patient consent Guardian consent obtained.

Provenance and peer review Not commissioned; externally peer reviewed.

(c) BMJ Publishing Group Ltd (unless otherwise stated in the text of the article) 2018. All rights reserved. No commercial use is permitted unless otherwise expressly granted.

\section{REFERENCES}

1 Vallasciani S, Atzori P, Martini L, et al. Scafoid megalourethra--a reliable surgical approach. J Pediatr Surg 2008;43:2128-30.

2 Ozokutan BH, Küçükaydin M, Ceylan H, et al. Congenital scaphoid megalourethra: report of two cases. Int J Urol 2005;12:419-21.

3 Nesbitt TE. Congenital megalourethra. J Urol 1955;73:839-42.

Copyright 2017 BMJ Publishing Group. All rights reserved. For permission to reuse any of this content visit

http://group.bmj.com/group/rights-licensing/permissions.

BMJ Case Report Fellows may re-use this article for personal use and teaching without any further permission.

Become a Fellow of BMJ Case Reports today and you can:

- Submit as many cases as you like

- Enjoy fast sympathetic peer review and rapid publication of accepted articles

- Access all the published articles

Re-use any of the published material for personal use and teaching without further permission

For information on Institutional Fellowships contact consortiasales@bmjgroup.com

Visit casereports.bmj.com for more articles like this and to become a Fellow 